\title{
A Correlative Study in the Modification of the BHK 21 Cell-line Induced by the Passage Within the Same Genotype
}

\author{
Vera Traykovich ${ }^{1}$ \\ Instituto Venezolano de Investigaciones Cientificas, Venezuela
}

Received September 24, 1968

\section{Introduction}

The oncogenic transformation of hamster cells in tissue culture can be produced under the influence of virus (Macpherson and Stoker 1962, Sachs and Medina 1961, Sanford and Hoemann 1967, Stoker and Macpherson 1961, Traykovich) and spontaneously in long term-culture (Defendi et al. 1963, Gotlieb-Stematsky and Shilo 1964, Hale et al. 1965, Sanford and Hoemann 1967, Stoker and Macpherson 1964, Thomas 1964, Traykovich 1968a). Last phenomenon has been first described in the kidney cells of the new born hamsters (Defendi et al. 1963, Gotlieb-Stematsky and Shilo 1964, Hale et al. 1965, Stoker and Macpherson 1964, Thomas 1964, Traykovich 1968a), known as continuous line BHK 21 of Macpherson and Stoker (1962), established in May 1961.

Defendi et al. in 1963 published about tumorigenic possibility of the BHK 21 cells, and other investigators confirmed this finding (Gotlieb-Stematsky and Shilo 1964, Hale et al. 1965, Stoker and Macpherson 1964, Thomas 1964, Traykovich 1968a).

The BHK 21 cells presented in this paper possessed high metastatic quality (Traykovich 1968a), for which they were distinguished from the other BHK 21 tumorigenic lines studied (Defend et al. 1963, Gotlieb-Stematsky and Shilo 1964, Hale et al. 1965, Stoker and Macpherson 1964). Aside from this, the cells have demonstrated possibility for heterotransplantation, the growth in recently born mice and rats, as well as on the chorio-allantoic membrane of the chicken eggs (Traykovich 1968b).

The aim of this study is to expose the correlation between the original BHK 21 culture, its development in the hamsters after implantation and its restoration from tumors in tissue culture. The experiment has been divided in three parts :

A) Characteristics of the original BHK 21 cells;

B) Behaviour of the cells grafted in the susceptible animals; and

C) Cellular characteristics after reestablishment of the tissue culture from the tumor.

1 Present address: Fábricas Químicas Ayacucho C.A. Apartado 6855, Caracas, Venezuela. 


\section{Material and methods ${ }^{1}$}

The BHK 21 cells at the beginning of the experiment were in the 18th laboratoric passage. They were maintained to the instruction of originators (Macpherson and Stoker 1962). The cellular layer was routinely transferred twice a week with glucosated trypsin solution (Tournier 1962).

The cytological study was performed on the cells grown in Leighton tubes, fixed in Boun's fluid and stained with hematoxylin and eosin.

The optimum concentration of cell dose for growth has been simultaneously determinated by the original BHK 21 cell line at the 47 th passage, and by the reestablished cell line of intradermal tumoral tissue (BHK 21/TID) at the 30th passage. The following quantity of cells : $5 \times 10^{4}-4 \times 10^{5} / \mathrm{ml}$ were set in six bottles of 2 ozs. During a period of five days a daily inspection was made of cell growth for the formation of complete layer on the surface of bottles, and in the case of acidification of the medium, this has been changed.

The chromosomes were elaborated by the Traykovich and col method (1967b) and colored with Unna stains. The modal (1967b) value has been estimated on the 82 BHK 21 cells, passage 19 and 21 , and on the 49 BHK 21/TID cells, passage 46 and 52 .

The implantation of the BHK 21 cells in the hamsters were made by the following manner: after trypsinisation and centrifugation on $800 \mathrm{rpm} / 10$ min, they were washed twice in Hanks' fluid. The desired dose was resuspended in the growth medium without serum.

For the orientational test on the tumorigenesis of the BHK 21 cells, the following grafts were made: subcutaneously, intradermal and intraperitoneal in doses of $5 \times 10^{6} / \mathrm{ml}$ in three groups of 6 adult animal conditioned with cortisone.

The mininum tumorigen dose of BHK 21 cells were determinated by comparativ mode, intradermal (ID) and subcutaneously (SC) inoculation in the back of hamsters with $1 \times 10^{6}-5 \times 10^{1} / \mathrm{ml}$ of cells in 14 groups of hamsters. Each group containing 6 hamsters, excepting one group of 5 animals.

The serial passages of the BHK 21 tumors were made, making six transplantable generation of the tumor tissue by intradermal and five by subcutaneous mode of grafts. The groups were composed of 6 animals, except in two cases of 7 .

169 adult hamsters (Mesocricetus auratus) were utilized in this experiment, 102 were autopsied. The tumor and lymph nodes were selected on the histological test, fixed in Boun's fluid and stained with hematoxylin and eosin.

Reestablishment cell culture of tumoral tissue were made in the following: one animal with subcutaneously grafted tumor (BHK 21/TSC) was sacrificed under ether narcosis. The fragments of well preserved tumor tissue were trypsinized and $4 \times 10^{5}$ of cells were planted in the bottles. Cell culture

\footnotetext{
1 Aknowledgment: Appreciation is expressed to Messrs. Lorgia Gutiérrez and Edith Marcano-Siminovic for their technical assistance.
} 

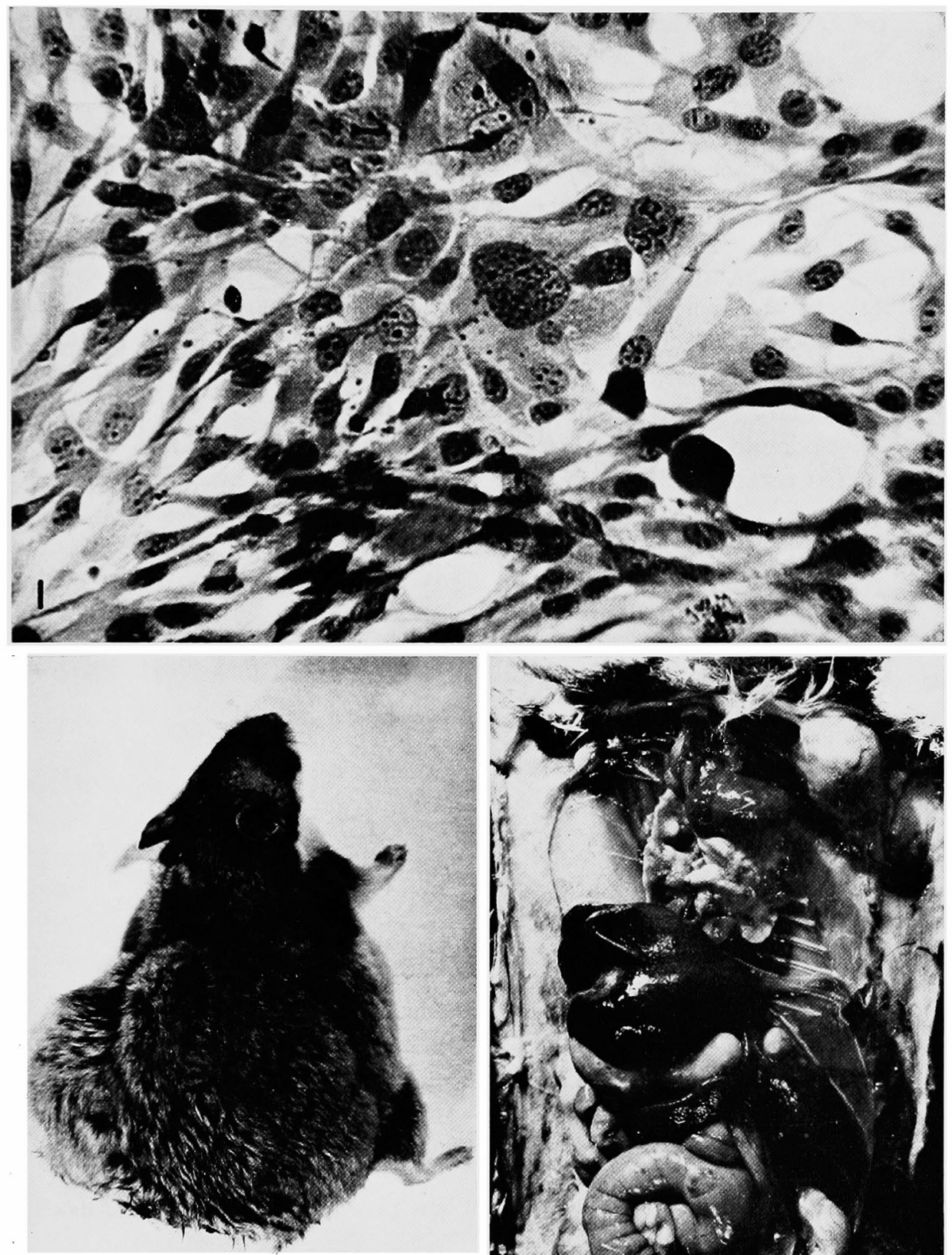

2

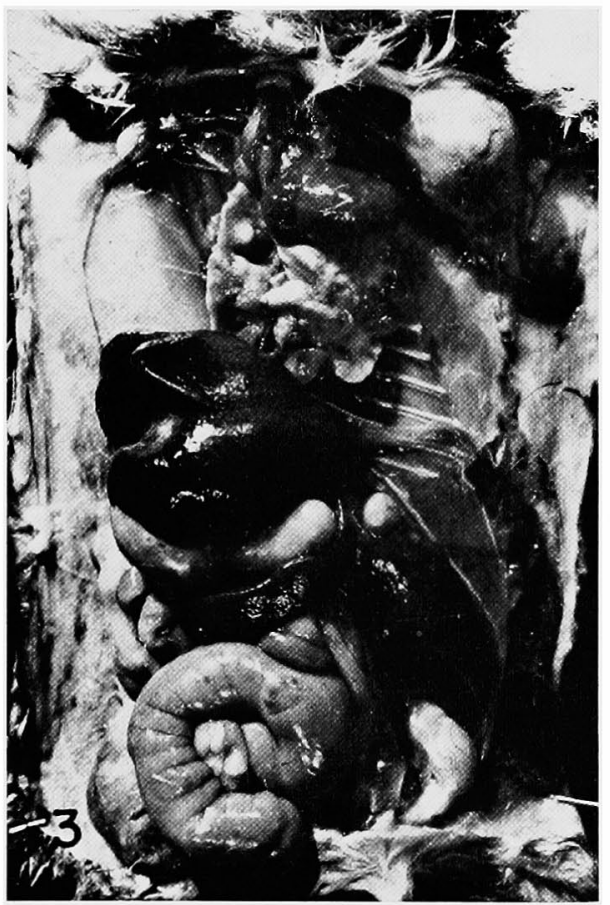

Figs. 1-3. 1, the TBK 21 culture with fusiform and epithelial-shaped cells and in the center a gigantic macrophage in the state of phagocytosis. Below in the right angle, a mitosis. Passage 19, 48 hours old culture. $\times 470$. 2, hamster with enormous BHK 21 tumor on the back. 3, hamster with metastasis in axillary and inguinal lymph nodes. Multiple metastatic foci in the lungs. A metastasis in the left kidney. Autopsy. 
of intradermal grafted tumors (BHK 21/TID) was elaborated on the same manner.

\section{Results}

A) Characteristics of the orginal BHK 21 cells. The cell layer was composed mostly of atypical spindle-shaped cells, than of poligonal epithelialshaped cells, connected by the cytoplasmic processes and gigantic epithelial phagocytes, approximately of $25-75 \mu$ in diameter. The last cells has uncommon nuclei with non uniform dispersed chromatine, which increased to 7 in number. In the nuclei have observed dark colored round, oval or irregular formed multiple nucleoli. The cells were criss-crossed oriented, indicating high metabolic activity, which could be registered by the rapid acidification of the medium (Fig. 1).

The optimum growth of cells were obtained with dose of $2,5 \times 10^{5} / \mathrm{ml}$, forming the complete layer within 78 hours apt to trypsinization (Charte 1 ).

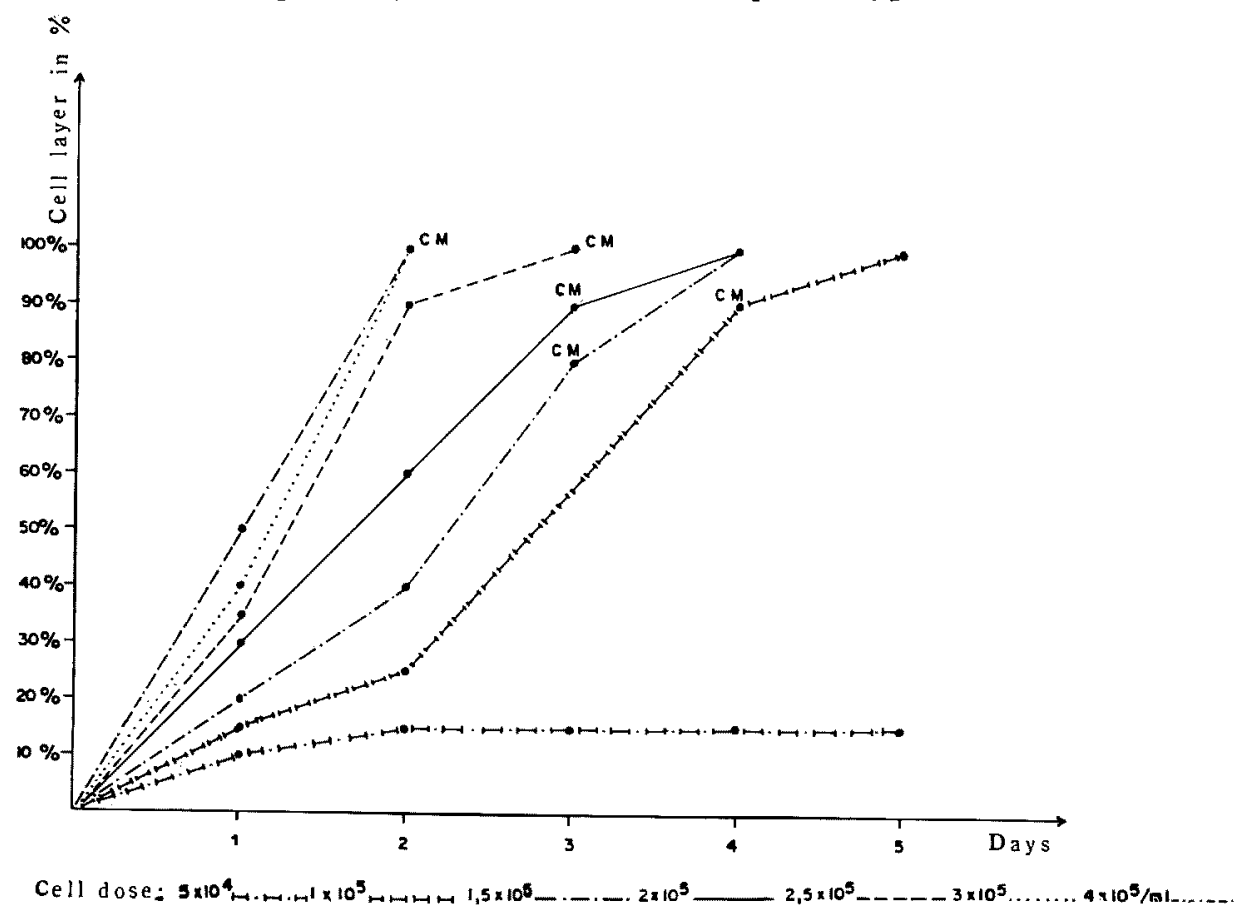

Chart 1. Curve of growth of the BHK 21 cell line, passage 47. CM: change of nutritive medium.

The enumeration of the chromosomes in the metaphase plate revealed the modal value of 43 , within the interval of 10-176. The majority of the cells have the chromosomes in the diploid area, next to hypo- and polyploid (Charte 2).

B) Behaviour of the BHK 21 cells in the hamsters. On the place of the inoculation of $5 \times 10^{5}$ cells, tumors appeared in all of the conditioned animals with cortisone, but with some difference. Intradermal implanted cells 


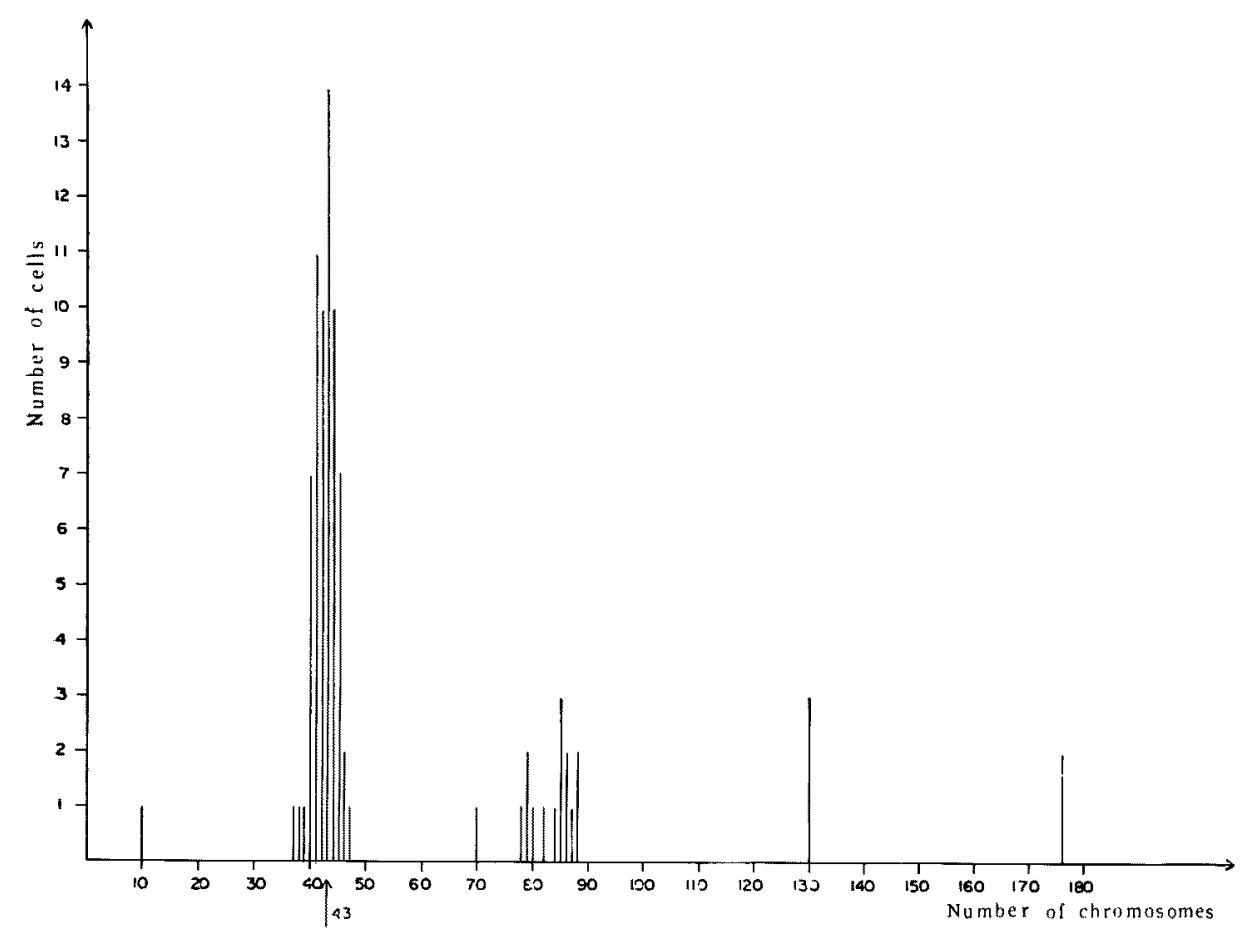

Chart 2. Chromosome number distribution of the BHK 21 cells passage 19 and 21.

produced the tumors with fast periferal necrosis, but intraperitonely tested animals had tumors with hemorrhagic ascites. Obtained results led to opine that it is a transformed cell line, which were confirmed by the next experiments.

The comparativ study revealed, that cell density for tumor producing was in extent from $1 \times 10^{8}-5 \times 10^{2} / \mathrm{ml}$, growing in $100 \%$ of inoculated non

Table 1. Development of tumors in the hamsters after implantation of BHK 21 culture, $\mathrm{P}-19$ and 20 within six months observation

\begin{tabular}{|c|c|c|c|c|c|c|}
\hline \multirow{3}{*}{ Cell density } & \multicolumn{6}{|c|}{ Inoculation } \\
\hline & \multicolumn{3}{|c|}{ ID } & \multicolumn{3}{|c|}{$\mathrm{SC}$} \\
\hline & Animals & $\begin{array}{c}\text { With } \\
\text { tumors } \\
\text { inoculated }\end{array}$ & $\begin{array}{l}\text { Latent } \\
\text { period } \\
\text { in days }\end{array}$ & Animals & $\begin{array}{c}\text { With } \\
\text { tumors } \\
\text { inoculated }\end{array}$ & $\begin{array}{l}\text { Latent } \\
\text { period } \\
\text { in days }\end{array}$ \\
\hline $1 \times 10^{6}$ & & $6 / 6$ & 7 & & $6 / 6$ & 9 \\
\hline $1 \times 15^{5}$ & & $6 / 6$ & 7 & & $6 / 6$ & 10 \\
\hline $1 \times 10^{4}$ & & $6 / 6$ & 7 & & $6 / 6$ & 12 \\
\hline $1 \times 10^{3}$ & & $6 / 6$ & 7 & & $6 / 6$ & 15 \\
\hline $5 \times 10^{2}$ & & $6 / 6$ & 23 & & $6 / 6$ & 29 \\
\hline $1 \times 10^{2}$ & & $4 / 5$ & 34 & & $5 / 6$ & 32 \\
\hline $5 \times 10^{1}$ & & $3 / 6$ & 40 & & $0 / 6$ & - \\
\hline
\end{tabular}



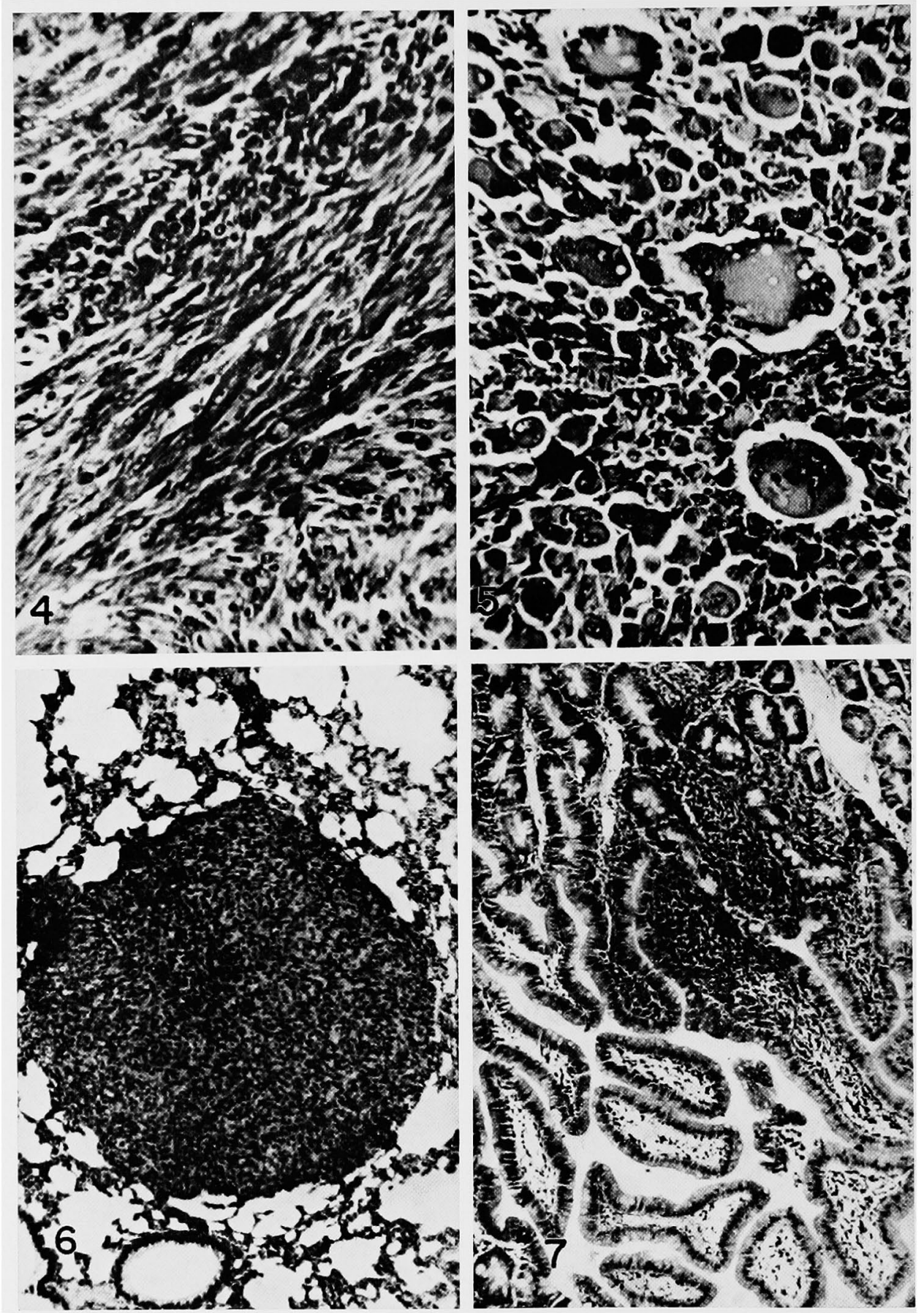

Figs. 4-7, 4, BHK 21 sarcoma with fusiform, round and globular cells, oriented in the fascicles and swirles, some in mitosis. Histological section. $\times 360$. 5, sarcoma with predominated round, globular cells and with acidophilic, monstruous gigantic cells, irregular vacuolated with bizzare multinucleated nuclei without fixed position, rounded with clear space. $\times 230$. 6, a large metastasis in the lung tissue composed of fusiform and round cells. $\times 90.7$, metastasis in the intestinal tract. The normal tissue is displaced by the presence of the metastsis. $\times 90$. 
conditioned animals for approximately of 7-23 days by the intradermal implantation, and for 9-29 days by the subcutaneous (Table 1). It can be seen from the same table, that ID method had more significant threshold for testing of tumorigen cell density, then $\mathrm{SC}$ one, because tumors developed with only 50 of cells in $3 / 6$ grafted animals.

Macroscopically tumor is presented as sarcoma of nodular surface, firm consistency, infiltrating the adjacent tissue, whitish, slightly vasculated and its growth reaching some time gigantic proportions; meanwhile the average weight was of $30-40 \mathrm{~g}$ (Fig. 2).

Microscopically tumor is polymorphous sarcoma, composed of slightly basophilic fibroblasts, round and globular cells, some in mitosis and less frequently bizzare, monstruous, gigantic, eosinophilic, multinucleated cells with cytoplasma sometimes irregular vacuolated. The nuclei of last cells did not have a fixed position, displaced to the periphery or in centre of cells. The cells measured approximatively up to $200 \mu$ in diameter and rounded with clear space. These forms of giant cells are rarely observed in the metastases.

Architectonically, the tumor did not have a definite model. Sometimes the cells are oriented in bunches or swirles, but more frequently without a definite orientation and with the blood vessels habitually of cavernous type (Figs. 3 and 4). The BHK 21 sarcoma was transplantable in series. They were made 6 passages of tumor by intradermal mode of grafts, and 5 by subcutaneous. The latent period of growth was shorter for the tumor grafted intradermal (4-5 days), than the tumor grafted subcutaneous (5-6 days, Table 2 ).

Table 2. Intradermic and subcutaneous passage of BHK 21 tumors in the hamsters

\begin{tabular}{|c|c|c|c|c|c|c|}
\hline \multirow{3}{*}{ Passage } & \multicolumn{6}{|c|}{ Implantation } \\
\hline & \multicolumn{3}{|c|}{ ID } & \multicolumn{3}{|c|}{$\mathrm{SC}$} \\
\hline & Animals & $\begin{array}{c}\text { With } \\
\text { tumors } \\
\text { inoculated }\end{array}$ & $\begin{array}{l}\text { Latent } \\
\text { period } \\
\text { in days }\end{array}$ & Animals & $\begin{array}{c}\begin{array}{c}\text { With } \\
\text { tumors }\end{array} \\
\text { inoculated }\end{array}$ & $\begin{array}{l}\text { Latent } \\
\text { period } \\
\text { in days }\end{array}$ \\
\hline 1 & & 6,6 & 5 & & $5 / 6$ & 5 \\
\hline 2 & & $6 / 6$ & 5 & & $6 / 6$ & 5 \\
\hline 3 & & 5,6 & 4 & & $5 / 6$ & 6 \\
\hline 4 & & 6,6 & 5 & & $6 / 6$ & 5 \\
\hline 5 & & $6 / 6$ & 4 & & $7 / 7$ & 5 \\
\hline 6 & & 7,7 & 4 & & - & - \\
\hline
\end{tabular}

The average life of the hamsters with BHK 21 sarcoma was about 60 90 days. The animals died with signs of cachexia and metastasis developed more frequently in the lymph nodes and lungs (Fig. 6), but presented them in variable percentage in all the organs. The disposition of metastases is presented on Table 3 and their number sharply increased 30 days after the tumor transplantation. 


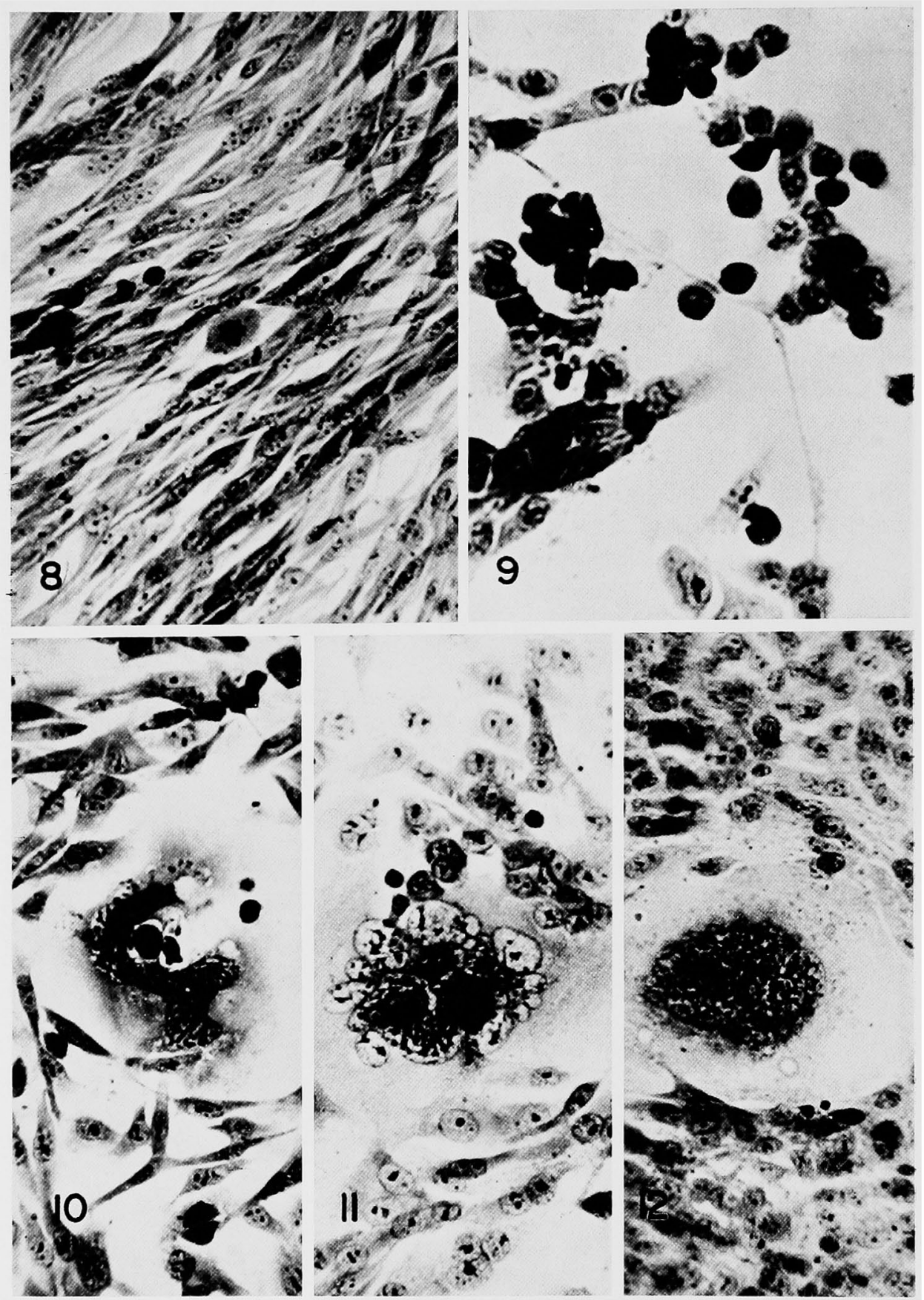

Figs. 8-12. 8, tissue culture of subcutaneous implanted tumor (BHK 21/TSC) composed of fine, lengthened fibroblasts with oval or round nuclei, oriented in one direction. In the center a mitosis. Passage 2, 48 hors. $\times 220$. 9, the BHK $21 /$ TSC culture, passage 7 demonstrates signs of degeneration. The cells are round, globular, pycnotic, croweded in irregular groups. Some atypical fibroblasts with extremly long cytoplasmatic prolongations. $\times 370$. 10 , culture of intradermal implanted tumor (BHK 21/TID), passage 15 . The cells 
C. Characteristics of the reestablished tissue cultures of the tumors.

a) The culture of the subcutaneous grafted tumor (BHK 21/TSC) has grown rapidly and abundant at the beginning, forming a layer within $72 \mathrm{~h}$., composed exlusively of fine, long and thin fibroblasts, oriented in one direction, with oval nucleus and chromatine in irregular masses (Fig. 8), having oval or round, dark nucleoli, one till five in number. Suddenly, from the 3 rd passage, the growth began to diminish gradually, demonstrating symptoms of degeneration with rounding and clumping of cells. It was noted the change of their morphology, the presence of round, globular, pycnotic cells and rare atypical, monstruous fibroblasts, having long cytoplasmatic prolongation, forming irregular groups of crowded cells, remaining clean spaces between them (Fig. 9), remplacing the normal form of fibroblasts. After the 7th passage, the culture had disappeared.

b) The culture of the intradermal grafted tumor (BHK 21/TID) within $72 \mathrm{~h}$ also formed a complete layer, but with a little abundance of cells. The initial growth was irregular with spindle and epithelial shaped cells and from 50th passage the culture has adopted a uniformly growth (Figs. 10-12). The monolayers were composed of irregular poligonal, exclusive epithelialshaped cells, presented round and oval nuclei, two or three in number and chromatin dispersed in the form of irregular balls and bands and with

are poligonal, epithelial formed and with scarce fibroblasts. In the center an enormous monstruous macrophagus with the nucleus acquiring the shape of a sickle at the moment of digesting cells. $\times 280$. 11, the BHK 21/TID culture, passage 28 . In the majority the cells are epithelial and some spindle-shaped. In the center a monstruous, gigantic macrophage with irregular, multiform polyglobulated nucleus at the moment of phagocytosis. $\times 220$. 12 , the BHK $21 / \mathrm{TID}$ cell line, passage 55 . The cell monolayer is composed of epithelial-shaped cells. In the center a monstruous, gigantic macrophagus with one enormous nucleus in the final phase of phagocytosis with detritus in the cytoplasma. $\times 240$.

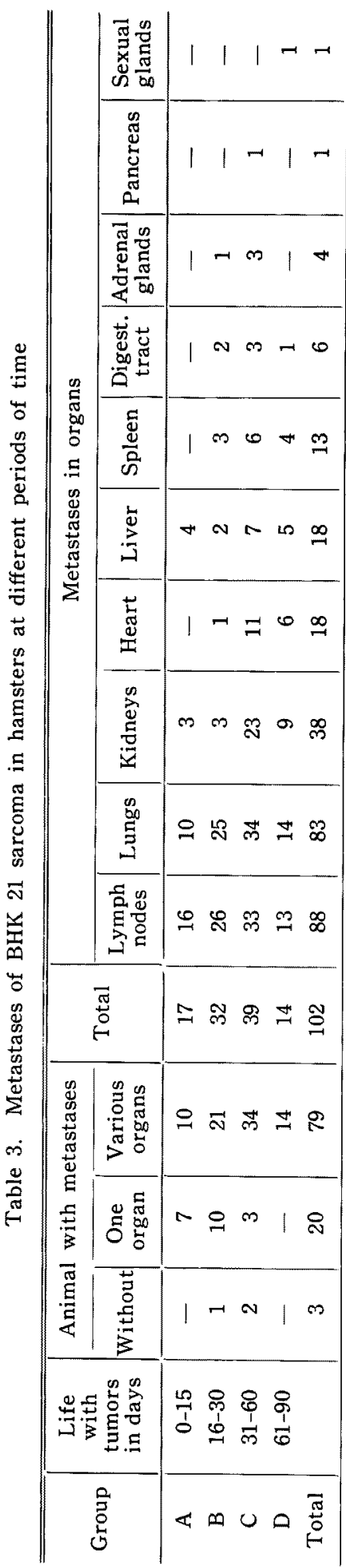


more than one dark nucleoli. It was noted too, the presence of extremly bizzare and monstruous macrophagos, exceptionally large, epitheliforme-shaped, approx.

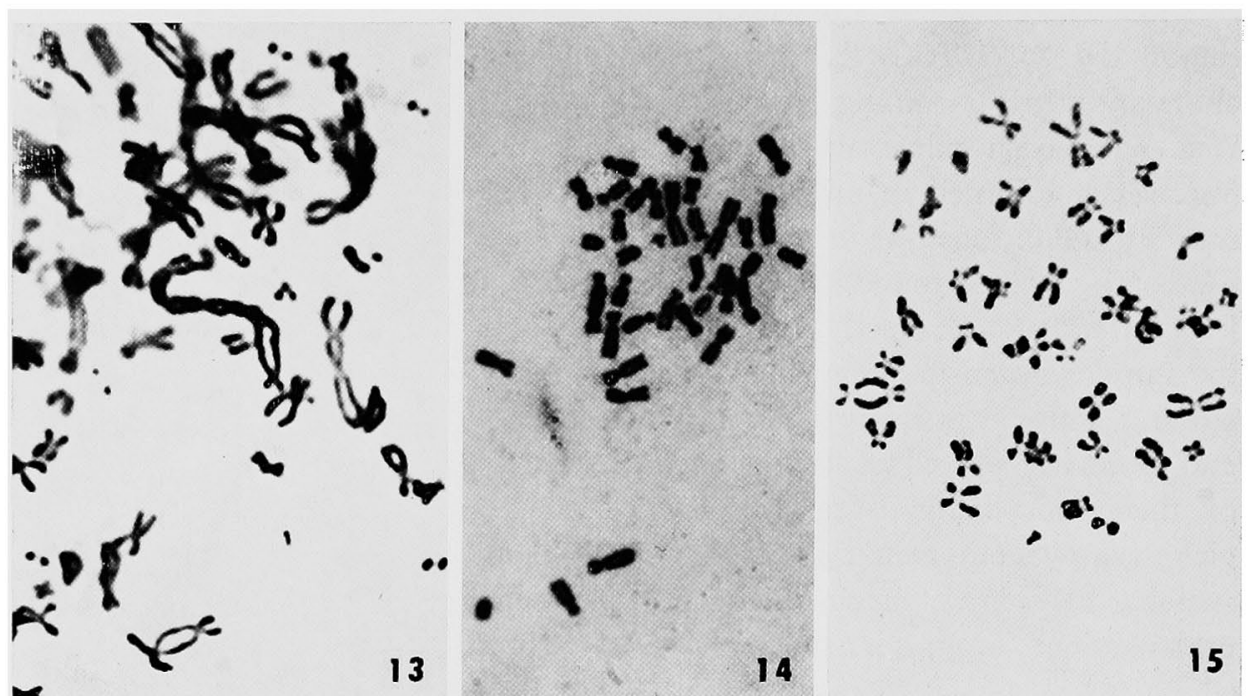

Figs. 13-15. Three figures of metaphase plates of BHK 21 cells. 13, part of a gigantic cell; unusual forms of chromosomes of BHK 21 cells; passage 19. 14, dicentric forms of chromosomes with large size in hypodiploid number; passage 19. 15, metaphase plate of BHK 21 cell; middle size of chromosomes with dicentric form; passage 19.

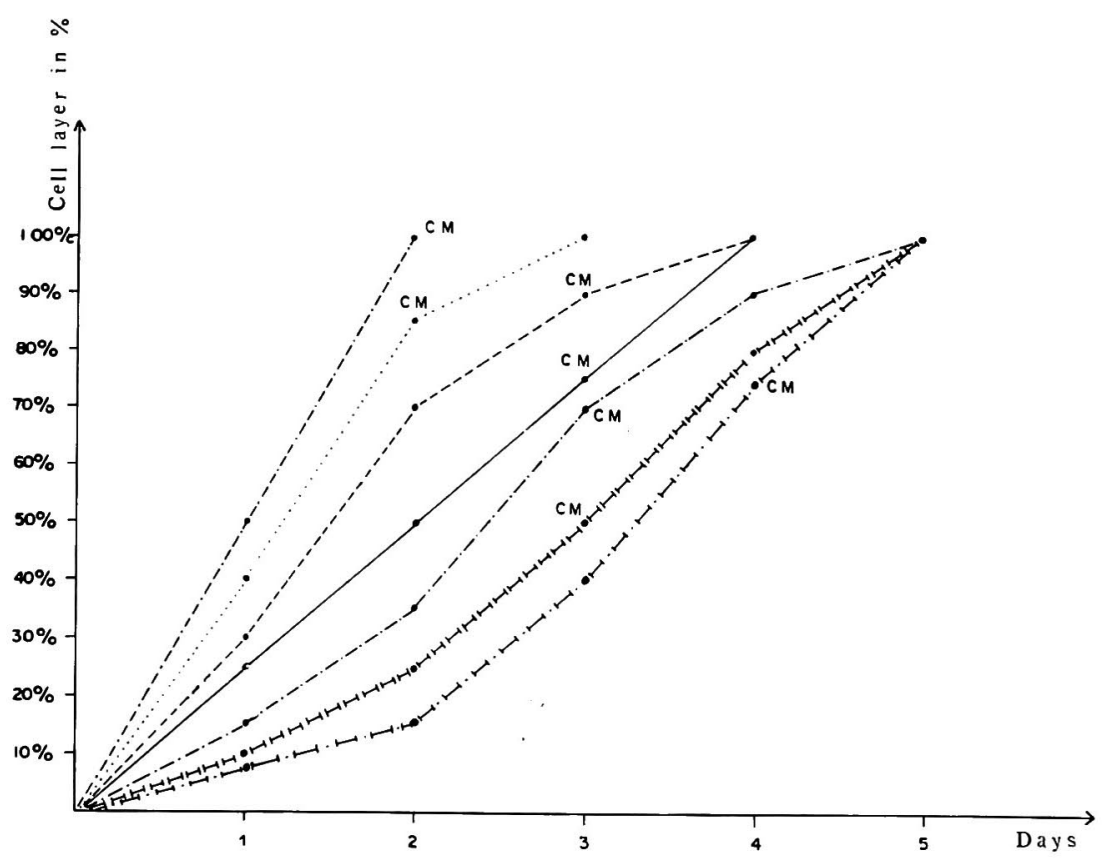

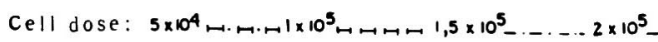
$2,5 \times 10^{5}----3 \times 10^{5} \ldots \ldots .4 \times 10^{5} / \mathrm{ml} \ldots \ldots$

Chart 3. Curve of growth of the BHK 21/TID cell line, passage 30 . CM: change of nutritive medium. 
75-350 $\mu$ and more, with particularly irregular nuclei in form and number, demonstrating a enormous possibility for phagocytosis (Figs. 10-12).

The optimum density of cells for growth were of $3 \times 10^{5} / \mathrm{ml}$, forming a complete layer within $72 \mathrm{~h}$ with intensive metabolism, giving cells in abundance (Chart 3).

The line acquired a modal value of 87 chromosomes with diapason of 2-397, demonstrating a high aneuploidy. The majority of cells had chromosomes in the diplo and tetraploid zone, besides hypo- and poliploidy (Chart 4).

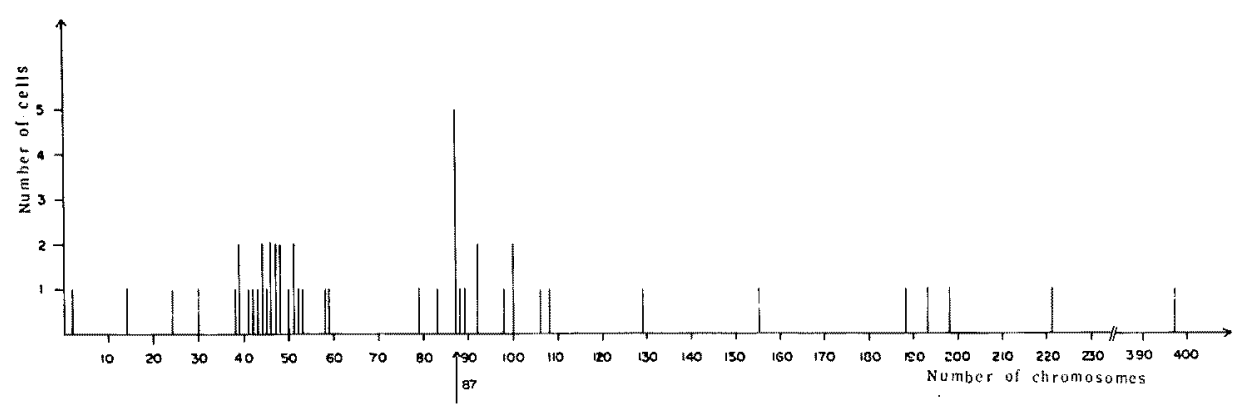

Chart 4. Chromosome number distribution of the BHK 21/TID cells passage 46 and 52.

\section{Discussion}

Based on the obtained results, it can be concluded, that presented BHK 21 cell lines have all characteristics of oncogenic converted cells : morphological heterology, chromosomal aneuploidy and high metabolic activity. These cells implanted in adult non-conditioned animals, induced infiltrate and metastasized pleomorphous sarcoma. Its possibility of growth in baby mice, rats and chorioallantoic membrane (Traykovich 1968b), verifies the oncogenic transformation of cells (Traykovich 1968a), produced spontaneously in long-term culture. From mentioned behaviour, the line is similar to the culture of spontaneous tumors (Moore et al. 1967, Traykovich and Rivière 1967a).

The new pecularities acquiered of the BHK 21 line under influence of the passage in the susceptible animals, were meaningful for the restored cultures of subcutaneously and intradermal grafted tumoral tissue.

The tissue culture of subcutaneous tumor (BHK 21/TSC) demonstrated in every sense as the normal fibroblastic culture with lengthened and thin spindle-shaped cells oriented in one direction, but without faculties for survival. This phenomenon can have these explanations: a) that the fragments of tumor used for the culture were composed of the mature fibroblasts, because the tumor was a polymorphous sarcoma; b) that the spindle-shaped cells present in the culture originated of conjunctival stroma of tumor tissue; or c) that the tumor in the culture for the unknown reason adapted the particularities of the normal cells by means of differentiation. This phenomenon in the culture of BHK 21/TSC normal tissue is uncommon and significant 
by the reversion of the tumor in the normal tissue.

On the other hand, the culture of intradermal grafted tumor also presented its particularity: epithelial structure of cells with very uncommon gigantic cells-monstruous macrophages. For these reasons, the line is clearly distinguished from the original BHK 21 culture (Table 4).

Table 4. Comparative characteristics between BHK 21 and BHK 21/TID cell lines

\begin{tabular}{l|c|c}
\hline \multirow{2}{*}{ Characteristics } & BHK 21 & BHK 21/TID \\
\cline { 2 - 3 } Morphology & $\begin{array}{c}\text { Majority cells spindle-shaped, } \\
\text { epithelial less and macro- } \\
\text { phages scarce, approx. diame- } \\
\text { ter 25-75 } \mu\end{array}$ & $\begin{array}{c}\text { Epithelial cells and scarce, } \\
\text { atypical, monstruous gigantic } \\
\text { macrophages, approx. diameter } \\
75-350 \mu \text { and more }\end{array}$ \\
\hline $\begin{array}{l}\text { Modal value and zonal } \\
\text { number of chromosomes }\end{array}$ & $\begin{array}{c}43 \\
\text { (hypoploide) } \\
10-176\end{array}$ & $\begin{array}{c}87 \\
\text { (hypotetraploide) } \\
2-397\end{array}$ \\
\hline $\begin{array}{l}\text { Optimum growth cell } \\
\text { concentration }\end{array}$ & $\begin{array}{c}2,5 \times 10^{5} \\
\text { Minimum tumoral cell } \\
\text { dose for the hamsters }\end{array}$ & $\begin{array}{c}\text { Appearence of tumors within } \\
\text { approx. 23 days by ID graft, } \\
\text { and 29 days by SC graft }\end{array}$ \\
\hline $\begin{array}{l}\text { Tolymorphous, metastatic and } \\
\text { transplantable sarcoma }\end{array}$ & $?$ \\
\hline
\end{tabular}

It is the opinion that the derivatives of BHK 21 cells, the TSC and TID cells have their origin in the original BHK 21 culture and also in the BHK 21 tumors, due to the fact that they contain similar cellular types. By means of the passage of original cells in the susceptible animals were effectuated cellular selection. Sanford et al. (1959) wrote about malignant increase of some cellular line of mice by the grafts within animals of the same genotype. Similar results have been reported by Klein et al. (1954). Garzcić and et al. (1965) also found certain changes in the properties of the $\mathrm{L}$ line after implantation in the $\mathrm{C} 3 \mathrm{H}$ mice and returned in to vitro conditions.

It was noted that the phase of adaptation have not existed for the BHK 21 tumors in the tissue culture, as in the case of spontaneous tumors of hamsters. This finding is in correlation with Stone's opinion (1962), that long-term cultures suffered the changes of genotype in the sense of tetra- and polyploid. The cells in these forms in the culture tissue are more adaptable, than the diploid cells for in vitro condition, that was the case with BHK 21 cells and theirs tumors.

In the culture of intradermal grafted tumors (TID) was observed the presence of the monstruous, gigantic macrophage with exceptionally uncommon bizzare nuclei (Figs. 10-12). This cellular type can be formed in the following manner due to imperfect karyodiaresis : a) by the synchronous or 
asynchronous mitosis of the nuclei ; b) by the endoreduplication of the chromosomes; or c) by the germination of the nuclei without cytodiaresis, obtaining a diameter of 75-350 $\mu$ and more (Figs, 10-12). These cells by means of agglomeration, phagocyte the others cells in which the nuclei actively intervenes (Figs. 10-12). It could be that the cannibalism is a manner of these macrophages to supply the indispensable nutritive material, besides the osmosis from the nutritive medium, present in the tissue culture. The preleminaries of these cells were found in the original BHK 21 culture, but having the dimension much more reduced and in tumor tissue (Fig. 5) too. The similar cells were also observed in the human tumoral tissue. Chomette D. et al. (1967) of the French school, described similar giant cell type in the bronchopulmonar epithelioma of the human species. One possible conclusion is made, that these monstruous macrophage in the tissue culture of the original BHK 21 line, in the tumors as well as in the BHK 21/TID line are identical cells, but uncommon in the metastatic foci because of their rare frequency, voluminosity and immobility.

It was concluded too, based on the results showed on Table 1 , that intradermal testing of cell density on potency for tumor producing has a significant threshold that of subcutaneous mode, and can be explained by richness of capillary network of the dermis, than the subcutaneous tissue.

\section{Summary}

It was presented a correlative study in the modification of BHK 21 cells, during its inoculation in hamsters, and after restoration the tissue cultures from tumors.

The original BHK 21 culture was composed of spindle-shaped, epithelialshaped cells and gigantic macrophage with diameter about 25-75 $\mu$, having chromosomal aneuploidy with modal value of 43 (hypoploid zone). The 500 BHK 21 cells grafted in hamsters produced in 100\% of animals metastasizing polymorphoys sarcoma with scarce bizzare macrophage and the tumors appeared after approx. 23 days by intradermal grafts and for approx. 29 days by subcutaneous. The tumor had fast growth, 4-6 days after grafting and the animals lived with tumors about 60-90 days. The intradermal testing of cell density for possible tumor producing has a significant threshold to that of subcutaneous mode.

There was obtained by the restoration of the tissue cultures from the tumors: a) the BHK 21/TSC culture from the subcutaneous grafted tumors, composed of fibroblasts, which disappeared in the 7 th passage by degeneration; and b) the new established BHK 21/TID cell line, originated from the intradermal grafted tumor. After the 50th passage, the TID line has deffnitely acquired uniformity, having epithelial-shaped cells and gigantic, monstruous macrophage, of diameter 75-350 $\mu$ and more, aneuplody and modal value of 87 chromosomes (hypotetraploid zone).

The difference obtained in the type of culture between the original BHK 
21 cells and its derivatives: the TSC and TID cultures was the consequence of selective passage of the cells within the susceptible animals.

\section{References}

Chomette, G., Auriol, M., Pinaudeau, Y., Brocheriou, C. and Depierre, R. 1967. Les épithéliomas broncho-pulmonaires a cellules géantes. Etude anatomo-clinique et signification. Bull. Cancer 54: 103-116.

Defendi, V., Lehman, J. and Kraemer, P. 1963. Morphologically "Normal" hamster cells with malignant properties. Virology 19: 592-598.

Garzičić, B. and Źivković, S. 1965. Changes of certain properties of cells inoculated into experimental animals and returned to in vitro conditions. Acta Med. Jugoslavica 19: 15-28, 1965.

Gotlieb-Stematsky, T. and Shilo, R. 1964. Studies on the tumorigenic properties of baby hamster kidney cell lines and a method of selection of high and low tumorigenic clones. Virology 22: 314-320.

Hale, J. H., Goffe, A. P., Thomlinson, B. E., Ingham, H. R., Weller, M. P. and Selkon, J. B. 1965. Studies on tumorous developing in hamsters following inoculation of Sv4O virus and BHK 21 cells. Brit. J. Exp. Path. 46: 598-606.

Klein, G., Klein E. and Revesz, L. 1954. Changes in histocompatibility induced by passage of tumors hybrid genotypes. Transpl. Bull. 1: 102-103.

Macpherson, I. and Stoker, M. 1962. Polyoma transformation of hamster cell-clones an investigation of genetic factors affecting cell competence. Virology 16: 147-151.

Moore, G. E., Mount, D., Tara, G. and Schwartz, N. 1967. Culture of malignant tumors of the Syrian hamster. J. Nat. Cancer Inst. 31: 1217-1237.

Sachs, L. and Medina, D. 1961. In vitro transformation of normal cells by polyoma virus. Nature (Lond.) 189: 457-458.

Sanford, K. K., Mervin, M. R., Hobbs, G. L. and Earle, W. R. 1959. Influence of animal passage on a line of tissue culture cells. J. Nat. Cancer Inst. 23: 1067-1077.

- and Hoemann, R. E. 1967. Neoplastic transformation of mouse and hamster cells in vitro with and without polyoma virus. J. Nat. Cancer Inst. 39: 691-703.

Stoker, M. and Macpherson, I. 1964. Syrian hamster fibroblast cell line BHK 21 and its derivatives. Nature (Lond.) 203: 1355-1357.

- and - 1961. Studies on transformation of hamster cells by polyoma virus in vitro. Virology 14: $359-370$.

Stone, D. 1962. Cell differentiation and carcinogenesis. Nature (Lond.) 194: 1039-1042.

Thomas, J. A. 1964. Evolution des tumeurs induites chez le hamster par inoculation intrapéritonéale des cultures de cellules BHK 21/13. C. R. Acad. Sc. Paris 258: 55545557.

Tournier, P. 1962. Glucosated trypsin solution and other technical advices for tissue culture. Personal communication.

Traykovich, V. and Rivière, M. R. 1967a. Certain characteristics and nuclear lesions in golden hamster melanoma cultures. Acta Path. Jap. 17: 107-115.

- and - 1967b. Eine Praktische Methode für die Erforschung der Hamster-Chromosomen in Vitro. Cytologia 32: 142-145.

- 1968a. A transplantable hamster's sarcoma produced by spontaneously transformed kidney cell line of baby hamster. J. Nat. Cancer Inst. 41: 1039-1050.

- 1968b. Heterotransplantability and transplantation resistance of spontaneously transformed baby hamster's kindney cell-line. In preparation.

-. Transformed hamster's embryo fibroblast cell-line (FC-L) with one agent of araguato monkey. In preparation. 